Anamarija Klišanić

Ines Vrsalović Nardelli

Dječji vrtić „Maksimir”

Zagreb, Hrvatska

ap1507976@gmail.com
UDK: 37.014.3(497.5)

Pregledni rad

Primljen: 4. 11.2021.

Prihvaćen: 10. 12. 2021.

DOI: https://doi.org/10.53406/kd.v9i2.25

\title{
SUVREMENO SHVAĆANJE DJETETA UNUTAR INSTITUCIJSKOG KONTEKSTA U HRVATSKOJ
}

Sažetak: Suvremena shvaćanja djeteta te uviđanje važnosti holističkog pristupa u cilju postizanja njegove maksimalne dobrobiti u području razvoja i učenja potaknula su na promišljanje teoretičare i praktičare. Pod utjecajem Nove paradigme djetinjstva, koja dijete vidi kao kreatora vlastitog odgojno-obrazovnog procesa, te u sinergiji teoretičara i praktičara iz područja odgoja i obrazovanja u Republici Hrvatskoj nastaje Nacionalni kurikulum za rani i predškolski odgoj i obrazovanje (2015). Za razliku od tradicionalnog shvaćanja djeteta i djetinjstva, usmjerenog više na produkt učenja negoli na njegov proces, suvremen pristup djetetu uvažava dijete kao kreatora vlastitog odgojno-obrazovnog procesa, uz zadovoljavanje sociopedagoške, prostorne i vremenske dimenzije koje se stalno isprepliću unutar institucijskog konteksta. Razumijevanje suvremenog kurikuluma koje djetetu prilazi na potpuno nov način podrazumijeva zajedničko učenje djece i odraslih u humanističkom i sociokonstruktivističkom okruženju. Odmicanje od tradicionalnog shvaćanja djeteta $i$ djetinjstva, u kojem se na njega gleda kao na prazno platno koje u institucionalnom kontekstu tek treba ispuniti, kao i prihvaćanje suvremenih spoznaja osvijestilo je važnost preispitivanja osobnih pedagogija praktičara. Takode, potaknulo ih je na cjeloživotno obrazovanje te osvijestilo potrebu razvoja kulture vrtića koja se očituje $u$ kvaliteti odnosa svih odraslih osoba i djece koji su uključeni u odgojno-obrazovni proces.

Ključne riječi: kompetencije, kultura ustanove, kurikulum, paradigme. 


\section{Uvod}

Tradicionalni pogledi na dijete dugi niz godina određivali su pristup odgoju i obrazovanju, kao i samom djetetu. Nekadašnji položaj djeteta u institucijskom kontekstu bio je nezavidan te se mnoga njegova prava nisu poštivala. Napredak znanosti uvelike je pridonio da se stara slika o djetetu počne mijenjati i sukladno $s$ tim da se institucije prilagode tim novim pogledima i shvaćanjima. Prve godine života vrlo su važne i imaju dugoročan utjecaj na ostatak života. Novije znanstvene spoznaje postale su s vremenom važan poticaj za nova promišljanja i u politikama koje utječu na oblikovanje institucijskog konteksta u kojem dijete uz obiteljski kontekst oblikuje svoju osobnost i svoja prva razmišljanja. Suvremeno shvaćanje djeteta dovelo je do mnogih pozitivnih promjena u institucijskom kontekstu koje idu u korist holističkom pristupu djetetu, s ciljem postizanja njegove maksimalne dobrobiti na svim područjima razvoja i učenja. Promijenjena paradigma u vezi djeteta i njegovog razvoja ušla je u brojne svjetske kurikulume ranog i predškolskog odgoja i obrazovanja (Apostolović, 2016; Miljak, 2007 i Previšić, 2007). Ministarstvo znanosti, obrazovanja i športa Republike Hrvatske 2007. godine odobrilo je projekt Nove paradigme ranoga odgoja iz područja predškolske i obiteljske pedagogije, u sklopu kojeg je nastala istoimena studija, koja se temelji na novoj slici djeteta kao aktivnog subjekta koji vlastitom participacijom unutar procesa odgoja i obrazovanja u velikoj mjeri ima priliku samo određivati vlastiti razvoj i život. Kao što je vidljivo iz prethodnog, u počecima kreiranja smjernica za rad ustanova ranog i predškolskog odgoja i obrazovanja koristio se izraz rani odgoj, no s vremenom se tom nazivu na području Republike Hrvatske dodaje i riječ predškolski, budući da uključuje djecu od 6 mjeseci pa do polaska u školu (Zakon o predškolskom odgoju, 1997; Državni pedagoški standard predškolskog odgoja i naobrazbe, 2008; Nacionalni kurikulum ranog i predškolskog odgoja i obrazovanja, 2015). Politike koje određuju rad ustanova ranog i predškolskog odgoja i obrazovanja na temelju znanstvenih istraživanja i sve većeg angažmana profesionalaca koji dolaze iz odgojno-obrazovne prakse uviđaju nužnost promjena, te u sinergiji teoretičara i praktičara iz područja odgoja i obrazovanja osmišljavaju Nacionalni kurikulum ranog i predškolskog odgoja i obrazovanja (2015) (u daljnjem tekstu: NKRPOO, 2015), koji se temelji na suvremenom shvaćanju djeteta i djetinjstva.

\section{Promjene u shvaćanju djeteta i djetinjstva kroz povijest}

Teoriju „tabula rasa” britanskog filozofa Johna Locka iz 17. stoljeća, po kojoj dijete na svijet dolazi kao "prazna ploča”, bez ikakvih predviđenih osobina, već se one razvijaju kroz njegovo odrastanje i upisuju na prazna mjesta (Bashayi, 2015), slijedili su kroz povijest mnogi teoretičari. Kako dječja spoznaja u to vrijeme nije bila predmet interesa odraslih, već se dijete poimalo objektom odgojno-obrazovnog procesa kojem odrasli nameću svoje stavove i vrijednosti, posebna istraživanja ranog razvoja djece nisu se provodila. Istaknuti znanstvenik Jean Piaget tijekom 20. stoljeća među prvima je počeo pomnije proučavati djecu i njihovo ponašanje, 
te je na temelju svojih empirijskih istraživanja razvio poznatu teoriju kognitivnog razvoja djeteta kroz nekoliko stupnjeva koji su bili u relaciji s godinama djeteta (Gopnik i sur., 2003). Piaget zaključuje da dijete uči, izgrađuje i shvaća svijet oko sebe u interakciji s okolinom te smatra da društvo ima moć utjecaja na razvoj djeteta samo kad je djetetovo razumijevanje u odgovarajućem stanju za promjenu. Ovakvi zaključci potvrđuju i temeljne pretpostavke pedagogije Marie Montessori i Waldorfske pedagogije (Balen, 2019; Bašić, 2011; Gomerčić, 2020; Jozipović, 2021; Seitz \& Hallwachs, 1996; Sviben, 2020; Wikefeldt, 2011; Zmajlović, 2016), koje se baziraju na prvim djetetovim iskustvima koja su osjetilne prirode, te je upravo to osjetilno opažanje glavni osnov za djetetovo upoznavanje i istraživanje svijeta koji ga okružuje (Maleš, 2011). Uzimajući u obzir sve prethodno navedeno, Lev Vygotsky (Pešikan, 2010) smatra da razvoj kreće od društvenog do onog unutar pojedinca, a individualizacija se gradi na temelju socijalizacije. Govor i sociokulturno iskustvo utječu na razvoj mišljenja jer upravo putem toga dijete dolazi u interakciju s okolinom iz koje dobiva znanje i informacije (Crowley, 2017). Upravo je ova nadogradnja u shvaćanju djeteta kao aktivnog sudionika vlastitog razvoja i učenja u svom kulturnom i socijalnom okruženju dovela do promjene $\mathrm{u}$ shvaćanju djeteta i djetinjstva općenito.

\section{Nove spoznaje na području razvojne neuroznanosti - važnost okruženja za optimalni razvoj djeteta}

Suvremena istraživanja (Vlastelica, 2014) potaknuta novim tehnologijama dokazuju da ako dijete prima slabu stimulaciju postojeće sinapse, odnosno veze u mozgu, one se neće razvijati, već će postupno nestati, dok se kod bogatih iskustava one osnažuju i stvaraju se nove. Tako su prvi mjeseci i godine života važniji nego su to znanstvenici ranije mislili. Plastičnost mozga (Robson i sur., 1996) je svojstvo koje tijekom djetinjstva omogućava savladavanje niza znanja i vještina. Bez obzira na to da je broj živčanih stanica rođenjem već određen, upravo nam plastičnost mozga pruža mogućnost njegovog kasnijeg razvitka, kao i stjecanja raznih složenih osobina važnih u daljnjem životu. Zanimljivo i „posebno intrigantno jest otkriće da učenje izaziva nastanak novih neurona i neuronskih veza” (Kandel, 1995, prema Vlastelica, 2014: 51). U kontekstu usvajanja jezika stručnjaci su počeli koristiti termin „kritičnih razdoblja” (Čizmić i Rogulj, 2018), što je osim usvajanja materinskog jezika vidljivo i na području usvajanja stranog jezika u kojem mlađa djeca daleko lakše usvajaju isti, te su kasnije u govoru puno sličniji izvornim govornicima određenog jezika nego su to kada uđu u period puberteta (Čizmić i Rogulj, 2018). Zahvaljujući istraživanjima o mozgu, znatno je unaprijeđeno i naše razumijevanje osjetljivih i kritičnih perioda razvoja kod djece kada se zbiva neko specifično učenje. To je od izuzetnog značenja za odgajatelje kao stručnjake koji bi se u svojoj praksi svakako trebali voditi novim istraživanjima kako bi odgoj i obrazovanje djece podigli na najvišu moguću razinu uzimajući u obzir dijete kao ogroman potencijal u svakom pogledu. Ovakve nove spoznaje temeljene na znanosti ( Siegel \& Pryne Bryson, 2015; Knudsen, 2004; Van Praag, Kempermann, \& Gage, 2000) pokrenule su brojne rasprave o važnosti ranog djetinjstva i njegovog velikog utjecaja na daljnji život čovjeka, koje bi trebale zasigur- 
no potaknuti i obrazovne politike da omoguće institucijama za rani i predškolski odgoj i obrazovanje optimalne uvjete u korist holističkog razvoja djeteta.

\section{Povijesni razvoj institucija ranog i predškolskog odgoja i obrazovanja}

Kako su shvaćanja djeteta prije bila osjetno drugačija nego li je to danas, sukladno s tim takav je bio i institucijski kontekst ustanova ranog i predškolskog odgoja i obrazovanja unutar kojeg su djeca živjela. U razdoblju do osamdesetih godina prošlog stoljeća prevladavalo je tzv. medicinsko doba dječjih jaslica (Petrović-Sočo, 2007), unutar kojeg je primat bila briga o zdravlju, ishrani, zaštiti i čuvanju djece, a odgoj kao takav odvijao se unutar obitelji s roditeljima kao primarnim odgajateljima vlastite djece. U Hrvatskoj su taj posao obavljale većinom medicinske sestre pedijatrijskog smjera i dadilje, na temelju čega se može zaključiti da je odgojno-obrazovna funkcija unutar ovih institucija bila neprimjetna $\mathrm{i}$ zanemarena, a djeca su boravila u sobama koje nisu bile pedagoški osmišljene i više su nalikovale na bolnice. Pod utjecajem novijih istraživanja na području razvoja i odgoja djece dolazi i do određenih promjena u shvaćanju institucijskog konteksta ranog i predškolskog odgoja i obrazovanja, na koji se počelo gledati kao na zajednicu u kojoj u socijalnoj interakciji žive djeca i odrasli. Nakon tzv. medicinskog doba dječjih jaslica započelo je poučavateljsko doba jaslica, koje u sebi sadrži pretpostavku da na djetetov razvoj i odgoj najbolje utječe izravno poučavanje u kruto definiranom rasporedu koji se popularno nazivao „režim dana”(PetrovićSočo, 2007). Položaj djeteta u ovakvom kontekstu bio je nezavidan, budući da se u ovakvoj strogo isplaniranoj sredini nije poštovao njegov individualni ritam življenja, pravo na različite izbore i mnoga druga prava koja su danas većini djece bar formalno zagarantirana (Konvencija o pravima djeteta, 2001). Promjene u predškolskoj odgojno-obrazovnoj praksi naše države donose dokumenti Prijedlog koncepcije razvoja predškolskoga odgoja (1991) i Programsko usmjerenje odgoja $i$ obrazovanja predškolske djece (1991), a služe kao stručna podloga za ostvarenje različitih programa odgoja i obrazovanja predškolske djece. U središtu demokratskoga odgojnog usmjerenja je dijete i njegove potrebe koje su dugo vremena bile u drugom planu. Prethodno navedeni dokumenti rezultat su suvremenih istraživanja na području razvoja, odgoja i obrazovanja djece rane i predškolske dobi, a temeljeni su na sociokonstruktivističkoj paradigmi, specifičnim potrebama i pravima djece te na ideji humanizma i pluralizma odgojno-obrazovnih ideja i koncepcija. Ove pozitivne povijesne prekretnice u pogledu na dijete u institucijskom kontekstu dovele su do boljeg razumijevanja njegovih potreba i načina na koje ono uči, te su dovele do stvaranja poticajnog okruženja u kojemu se potiče njegova neovisnost i autonomija (Bruner, 2000). Također se na instituciju počelo gledati kao na zajednicu učenja djece (Slunjski, 2008) koja potiče djecu na samoinicijativno i samoorganizirano učenje, što im omogućava upravljanje procesima vlastitog učenja uz preuzimanje odgovornosti. Kao važan kriterij za maksimalizaciju dječjeg ostvarenja stručnjaci često spominju i razinu ugode koju djeca osjećaju unutar institucijskog konteksta, koji bi trebao sve više nalikovati toplom obiteljskom okruženju u kakvom se djeca nesmetano mogu razvijati, izražavati i učiti u isto vrijeme. 


\section{Različite dimenzije konteksta ustanove ranog i predškolskog odgoja i obrazovanja i tvorba suvremenog kurikuluma ranog i predškolskog odgoja i obrazovanja}

Unutar konteksta ustanove ranog i predškolskog odgoja i obrazovanja postoje sociopedagoška, prostorna i vremenska dimenzija (Petrović-Sočo, 2007), koje su isprepletene te snažno utječu na razvoj i učenje djeteta. Odgojno-obrazovna praksa koja se odvija unutar njih je specifična budući da se unutar nje odvijaju dinamične interakcije koje se svakodnevno mijenjaju i nadopunjuju ovisno o sudionicima. Opremljenost prostora i njegov raspored ukazuju na određene stavove, norme, uvjerenja i očekivanja zaposlenih u odgojno-obrazovnoj ustanovi te šalju snažnu poruku kako oni kao profesionalci gledaju na dijete i koliko ga uvažavaju kao aktivnog sukreatora vlastitog razvoja i učenja. Kao najvažniju dimenziju unutar ovog konteksta mogli bismo navesti sociopedagošku dimenziju, unutar koje se odvijaju svakodnevne interakcije djece i svih odraslih koji dolaze u dodir s njima u ustanovama ranog i predškolskog odgoja i obrazovanja. Osim mnoštva interakcija, važan čimbenik ove dimenzije je i ugodno psihopedagoško ozračje (Petrović-Sočo, 2007). Sociopedagoška dimenzija povezana s prostornom i vremenskom dimenzijom čini dinamičnu mrežu socijalnih, kulturalnih i ekoloških odnosa unutar njega. Suvremeno osmišljeni prostorni i materijalni uvjeti u ustanovi uvelike mogu pridonijeti funkcioniranju socijalnog podsustava, koji na isti način može svojim kvalitetnim interakcijama pridonijeti boljem razumijevanju i prostorne i materijalne okoline koja tada postaje poticajna za dijete i pomaže mu da razvije svoje pune potencijale. Uloga odgajatelja unutar konteksta ustanove ranog i predškolskog odgoja i obrazovanja može se smatrati ključnom ako u obzir uzmemo da je upravo on taj koji u svakodnevnoj socijalnoj interakciji s djetetom na njega uvelike utječe svim svojim bićem (Lazić i Colić, 2017). Unatoč značajnog djelovanja sociopedagoške dimenzije na razvoj i odgoj djeteta, ne treba zanemariti i njegove ostale dimenzije. Prostorna, odnosno fizička dimenzija koju čine organizacija i raspored prostora, materijala i raznih igračaka utječe na kvalitetu i učestalost socijalnih interakcija te djeluje na ozračje u ustanovi. Važno je da su materijali i igračke namijenjene djeci dostupni na policama koje su otvorene te da su održavani. Neovisnost, interakcija i kretanje osnovna su tri zahtjeva koje bi prostor trebao zadovoljiti kako bi omogućio svoj djeci maksimalan individualni i grupni rast i razvoj (Petrović-Sočo, 2007). Vremenska dimenzija unutar konteksta ustanove ranog i predškolskog odgoja i obrazovanja trebala bi omogućiti zadovoljenje individualnih potreba djece, unutar koje odgajatelji trebaju dati svakom djetetu vremena za jelo, oblačenje i svlačenje, obavljanje nužde te igranje, ovisno o njegovim vlastitim sposobnostima i tempu bez požurivanja. Dnevni raspored trebao bi biti samo okvir, a dob djeteta, stupanj razvoja, potrebe i želje roditelja i individualne potrebe i želje djece trebale bi kreirati svakodnevnicu. Bitno načelo vezano uz vremensku dimenziju je načelo fleksibilnosti (NKRPOO, 2015), prema kojem nije primjereno postavljanje krutih vremenskih okvira u odnosu na djecu, budući da oni „ograničavaju prihvaćanje individualno različitih ritmova djece tj. usporavaju i/ili onemogućavaju puninu razvoja njihovih potencijala" (NKRPOO, 2015: 4). 
Kako bi se različite dimenzije konteksta ustanove ranog i predškolskog odgoja i obrazovanja uobličile u zajednički okvirni program, stručnjaci osmišljavaju kurikulume koji u sebi sadrže određena načela, vrijednosti i ciljeve koji bi trebali biti najviše u službi djeteta. Da to nije oduvijek bilo tako, zasigurno se može vidjeti na primjeru nekadašnjeg tradicionalnog kurikuluma ranog odgoja, koji je za cilj imao usvajanje znanja direktnim poučavanjem, odnosno transmisijom od strane odgajatelja. Ovakvi, možemo slobodno reći pomalo upitni ciljevi, bili su uvelike odraz potreba i ciljeva društva koje je na taj način bilo više usmjereno na produkt negoli na sam proces, koji je u suvremenom kurikulumu osnova rada s djecom. Držeći se krutih normi i transmisije znanja, djeca su se uprosjećivala, budući da se nije previše vodilo računa o individualnim razlikama, a upravo one su vrlo bitne $\mathrm{u}$ procesu izgradnje znanja, te podrška odgajatelja svakako treba biti individualna, a ne unificirana. Odgajatelji bi unutar tradicionalnog kurikuluma godinu dana unaprijed isplanirali odgojno-obrazovne aktivnosti koje su se zatim provodile u obliku frontalnog rada, fragmentirane po različitim područjima unutar kojih se znanje provjeravalo učenjem napamet, dok se razumijevanju nije pridavao značaj (Petrović-Sočo, 2009). U suvremenom kurikulumu prethodno navedeni načini rada u najmanju ruku su nepoželjni te bi se svaki odgajatelj trebao voditi načelima fleksibilnosti, kako organizacijskih tako i vremenskih i prostornih. Fleksibilno oblikovan odgojno-obrazovni proces djeci omogućuje izražavanje inicijativa te njihovih prijedloga i sugestija koje se trebaju uvažavati i na osnovu kojih bi se trebalo temeljiti planiranje aktivnosti koje su onda u skladu s trenutnim interesima djeteta. Umjesto frontalnog rada, prilikom kojeg je odgajatelj svojevrsni vođa aktivnosti, prednost se danas daje samoorganiziranim aktivnostima djece, u kojima je odgajatelj pomagač i promatrač koji dokumentira dječje aktivnosti i socijalne interakcije. One pomažu u stvaranju što bolje slike o djetetu budući da ga se pritom promatra u njegovim spontanim kreacijama tijekom igre, čija je funkcija i danas dosta podcijenjena budući da šira javnost nije dovoljno dobro upoznata s mnogostrukim dobrobitima koju igra ima u životu djece. Posebice su simboličke igre te koje razvijaju socijalne kompetencije djeteta (Jurčević-Lozančić, 2011) jer se tijekom njih ono prilagođava trenutnim situacijama i različitim ulogama koje djeca spontano preuzimaju pretvarajući svoja iskustva iz života u njima smislene konstrukcije. Razumijevanju suvremenog kurikuluma prilazi se na potpuno nov način kroz prizmu zajedničkog života i učenja odraslih i djece u humanističkom i sociokonstruktivističkom okruženju. Težnju ka suvremenom pristupu ranom i predškolskom odgoju i obrazovanju na području Hrvatske prepoznale su i obrazovne politike, koje su potaknule izradu novog, suvremenog kurikuluma za rani i predškolski odgoj, koji je osmišljen uzimajući u obzir najnovija istraživanja te europska i svjetska iskustva pri njegovom uobličavanju. NKRPOO (2015) u sebi sadrži temeljne vrijednosti, načela i ciljeve umjesto sadržaje o odgoju i obrazovanju. Osim prethodno navedenih temeljnih odrednica NKRPOO (2015), jedno od bitnih obilježja ovog dokumenta je i usmjerenost na razvoj ključnih kompetencija za cjeloživotno učenje, kojima je posvećena posebna pažnja upravo zbog njihovog dugoročnog utjecaja na život djeteta i povezanosti s razvojem pozitivne slike o sebi te razvojem samopouzdanja, samopoštovanja i zdrave samosvijesti. O značaju stvaranja ugodnog psihopedagoškog ozračja unutar psihopedagoške dimenzije 
u kontekstu ustanove ranog i predškolskog odgoja i obrazovanja vodilo se računa i u oblikovanju hrvatskog NKRPOO (2015), unutar kojeg je posebno mjesto zauzela kultura vrtića koja se očituje u kvaliteti odnosa svih odraslih osoba i djece koji su uključeni u odgojno-obrazovni proces. Demokratičnost je jedna od temeljnih postavki na kojoj kultura vrtića počiva i koju odrasli u svojstvu modela svjedoče djeci (Petrović-Sočo, 2008) učeći ih poštivanju i prihvaćanju različitosti po načelima humanizma i tolerancije (NKRPOO, 2015). Kako bi se održala visoka razina kvalitete odgojno-obrazovne prakse unutar ustanova ranog i predškolskog odgoja i obrazovanja, važnu ulogu ima i unutarnja procjena kvalitete koju uvjetuje osposobljenost svih čimbenika (roditelja, djece, odgajatelja i drugih stručnih djelatnika u vrtiću) za kvalitetnu i kontinuiranu samoprocjenu (NKRPOO, 2015). Osim unutarnje procjene kvalitete, postoji i vanjsko vrednovanje koje provode profesionalci iz drugih vrtića te institucije poput Ministarstva znanosti i obrazovanja, Nacionalnog centra za vanjsko vrednovanje obrazovanja, Agencije za odgoj i obrazovanje i dr., po unaprijed dogovorenim i međusobno usklađenim kriterijima, a sve u svrhu uklanjanja određenih nedostataka i unapređenja „postojećega najboljeg" (NKRPOO, 2015: 28).

\section{Nove paradigme u ranom i predškolskom odgoju i obrazovanju}

Nakon razdoblja u kojima se na dijete gledalo kao na objekt odgojno-obrazovnog procesa, suvremena istraživanja su pridonijela stvaranju jedne nove, suvremene slike djeteta. Ključno za suvremenu sliku djeteta je shvaćanje da su upravo prve godine života one tijekom kojih dijete usvaja spoznajne modele koje pronalazi u svom okruženju te sociokulturna dimenzija koja vodi dijete prema razumijevanju i određivanju putova i obrazaca kojima će se voditi u daljnjem životu i koji će obilježiti način na koji ono razumije, nadograđuje i mijenja svijet oko sebe (Slunjski, 2012). U sklopu projekta koji je okupio 14 hrvatskih znanstvenica iz područja predškolske i obiteljske pedagogije te kojeg je 2007. godine odobrilo Ministarstvo znanosti, obrazovanja i športa Republike Hrvatske nastala je studija Nove paradigme djetinjstva, koja u sebi sadrži lijepo uokvirenu novu sliku djeteta koja daje naglasak na osobnost djeteta od samog rođenja i njegovu aktivnu ulogu kao socijalnog subjekta koji na razne načine određuje sudbinu vlastitog razvoja i života. Nova slika djeteta prikazuje ga kao aktivnu i kompetentnu individuu koja se u socijalnom kontekstu razvija vlastitim tempom. Osim novih shvaćanja da dijete najbolje uči čineći, u konstrukciji i sukonstrukciji znanja, u odgojno-obrazovnom procesu bi se trebalo voditi računa o djetetovim vlastitim teorijama i različitim strategijama prilikom kojih ono kritički propituje i na određen način upoznaje svijet oko sebe. U svom fizičkom i socijalnom okruženju dijete je svojevrstan istraživač koji se angažira u aktivnostima koje su za njega svrhovite. Tek kada odgajatelji daju djetetu slobodu da uživa u ovakvim samoiniciranim i samoorganiziranim aktivnostima (Slunjski, 2012), oni kao aktivni promatrači mogu na temelju različitih načina dokumentiranja planirati zajedno s djecom daljnje aktivnosti koje su onda proizašle iz stvarnih interesa djeteta, a nisu nametnute izvana od strane odraslih koji mogu često krivo procijeniti njegove trenutne in- 
terese ukoliko se ne usredotoče na samo dijete i to što ono radi i govori. Budući da je osjećaj suglasnosti s okolinom jedan od važnih čimbenika koji dovode do zdravog razvoja djeteta, stvaranje povjerenja, odnosno sigurnosti da se može suočiti bez straha sa mnogobrojnim zahtjevima koje život stavlja pred njega te da zna i vjeruje da može savladati prepreke i probleme na koje putem naiđe od iznimne je važnosti.

\section{Suvremeni kontekst ustanove ranog i predškolskog odgoja i obrazovanja}

Suvremeni kontekst ustanove ranog i predškolskog odgoja i obrazovanja mora se temeljiti na shvaćanju djeteta kao socijalnog subjekta, cjelovitog bića i istraživača koji je aktivni stvaratelj znanja i sukonstruktor pri osmišljavanju vlastitog života i okruženja unutar nje. Odgojno-obrazovni proces unutar ustanove trebao bi biti oblikovan tako da omogućuje istodobno sudjelovanje u različitim aktivnostima koje su djeca sama inicirala i organizirala. U tom procesu odgajatelj ima također važnu ulogu da oblikuje okolinu koja će za dijete biti izazovna i poticajna za istraživanje različitih fenomena te potiče na interpretacije višestrukim propitivanjem raznih pretpostavki i zaključaka. U suvremenom kontekstu ustanove ranog i predškolskog odgoja i obrazovanja djeci su osigurana prava jednakosti (Konvencija o pravima djeteta, 2001) te prava na inkluzivni odgoj (UNESCO, 2005) za svu djecu koja na taj način postaju punovrijedni članovi društva. Unutar ovog konteksta nužno je prihvaćanje svake različitosti, bilo individualne vezano uz dijete, bilo različitosti pojedinih obitelji, posebice ako dolaze iz socijalno i ekonomski loših uvjeta. Pravo djeteta na aktivno sudjelovanje u ostvarivanju vlastitih prava važno je kako bi im se omogućilo da utječu svojim mišljenjem i iskustvima na vlastiti život i budućnost (Woodhead, 2012). U ustanovi ranog i predškolskog odgoja i obrazovanja trebala bi postojati vizija koja je svojevrsni pokretač aktivnosti u njoj, a oblikovanje te vizije zajednički je posao svih djelatnika vrtića. Kultura vrtića još je jedna bitna odrednica suvremenog konteksta ustanove te je ona rezultat zajedništva svih koji borave u njemu. Većina suvremenih autora (Krstović, 2009; Lozančić, 2011; Miljak, 2009; Pešikan, 2010; Rogulj, 2018; Slunjski, 2012; Petrović-Sočo, 2009) smatra da dijete ne možemo promatrati kao pasivnog konzumenta kulture, već kao subjekt koji od najranijih dana sukonstruira kako u vlastitoj obitelji, tako i $\mathrm{u}$ institucijskom kontekstu. Kontekst se mijenja pod utjecajem promjena u kulturi, ali se isto tako kultura mijenja pod utjecajem ljudi u kontekstu. Stoga se može zaključiti da su profesionalci koji djeluju unutar konteksta ustanove RPOO-a ti koji bi svojim znanjima i profesionalnim i osobnim kompetencijama trebali mijenjati kulturu društva u kojoj bi se više vodilo računa o suvremenom shvaćanju djeteta te važnosti institucijskog konteksta za kvalitetno i socijalno kompetentno funkcioniranje budućih naraštaja, što se neminovno odražava i na društvo u cjelini. Upravo su praktičari ti koji na temelju vlastitih akcijskih istraživanja koja provode s djecom mogu i dalje mijenjati sliku djeteta te na taj način mijenjati i sam institucijski kontekst na bolje. 


\section{Uloga odgajatelja u ranom i predškolskom odgoju i učenju djeteta}

Ulogu odgajatelja u ranom i predškolskom odgoju i učenju djeteta mogli bismo povezati s idejom novog profesionalizma, koja od njega zahtjeva napuštanje tradicionalnih pristupa ranom odgoju i učenju i prihvaćanje nove slike o djetetu i djetinjstvu kroz mijenjanje vlastitih paradigmi i „mentalnih modela” (Senge, 2003 prema Sočo, 2009). Vođen novom paradigmom, suvremeni odgajatelj utječe na cjelokupni odgojno-obrazovni proces te se njegova uloga temelji na ideji socijalnog konstruktivizma i poticanju metakognitivnih sposobnosti u procesu učenja djeteta (Čeko, 2021; Gray \& MacBlain, 2015; Grđan, 2008; Miljak, 2007; NKRPOO, 2015). Budući da je rani i predškolski odgoj i obrazovanje dinamičan i interaktivni proces, on zahtjeva i visok stupanj profesionalnosti, što podrazumijeva i kontinuirano cjeloživotno obrazovanje koje omogućava razvijanje osobnih i moralnih vrijednosti, koje odgajatelj svakodnevno svjedoči djeci (Petrović-Sočo, 2008). Autorica Slunjski (2012) naglašava važnost odgajateljeve sposobnosti stvaranja organizacijskih uvjeta u kojima djeca mogu učiti i razvijati svoje potencijale kroz konstrukciju i sukonstrukciju znanja. Odgajateljeva koncepcija o djetetu oblikuje i njegov pristup odgoju i obrazovanju, koji bi trebalo biti oblikovan pomnim promatranjem i aktivnim slušanjem djece kako bismo osim objašnjenja što to djeca čine, mogli kroz razmjenu mišljenja i poštivanja dječje perspektive odrediti i ono što misle da čine i koji su razlozi da to čine (Bruner, 2000). U ranom i predškolskom odgoju i učenju djeteta posebno mjesto zauzima visok stupanj fleksibilnosti odgajatelja koji mu omogućava da u samom procesu učenja ima sposobnost promatranjem djeteta i njegovih aktivnosti odustati od planiranog ili pak očekivanog smjera djetetovih aktivnosti prihvaćajući djetetove zamisli i inicijative (Slunjski, 2012). Na taj se način „potiče autonomija i emancipacija djece u procesu učenja i prihvaća njegova vlastita dinamika i samoregulacijske snage" (NKRPOO, 2015: 16-17).

\section{Zaključak}

Pod utjecajem novih spoznaja iz područja razvojne neuroznanosti, koja je donijela opipljive dokaze ranom razvoju mozga i skrenula pozornost na značaj ranog djetinjstva, stara slika djeteta kao objekta odgojno-obrazovnog procesa uvelike se promijenila. Ovakva istraživanja ukazala su na izuzetnu važnost ranih stimulacija, koje imaju velik utjecaj na djetetov razvoj i učenje. Suvremeno shvaćanje djeteta potpomognuto je novijim znanstvenim dostignućima i uvelike je promijenilo odnos prema njemu i u samom institucijskom kontekstu. Teoretičari i praktičari su u suglasju pri shvaćanju djeteta kao socijalnog bića koje kroz niz socijalnih interakcija u koje je svakodnevno uključeno razvija višestruke kompetencije za koje se pokazalo da uvelike utječu na dobro funkcioniranje u odrasloj dobi. Institucijski kontekst se pod utjecajem znanstvenih istraživanja morao mijenjati jer je suvremeno shvaćanje djeteta pokrenulo rasprave i o neposrednoj okolini koja utječe na njega, a to je uz obiteljski kontekst iz kojeg dijete dolazi u današnje vrijeme sve više i odgojno-obrazovna institucija, na koju se počelo gledati kao na dječju kuću 
u kojoj se ono mora prvenstveno osjećati ugodno i prihvaćeno te u kvalitetno pripremljenoj okolini imati priliku razvijati svoje pune potencijale. Stručnjaci koji rade u ustanovama ranog i predškolskog odgoja i obrazovanja također moraju konstantno razvijati svoje profesionalne i osobne kompetencije tijekom cjeloživotnog učenja kako bi bili u stanju prepoznati i zadovoljiti raznolike potrebe i interese suvremenog djeteta, imajući na umu da je djetinjstvo životno razdoblje sa vlastitim vrijednostima i kulturom, koje je vrijedno poštovanja i uvažavanja. Suvremeno shvaćanje djeteta upotpunjeno s visokim osobnim i moralnim vrijednostima profesionalaca u kontekstu ranog i predškolskog odgoja i obrazovanja omogućuje djeci životno učenje i njegovanje vrijednosti, odgovornosti, tolerancije, demokracije i identiteta.

\section{Literatura}

Apostolović, D. (2016). Kurikulumi predškolskog vaspitanja kao osnova za planiranje i programiranje rada vaspitača u predškolskoj ustanovi. U: E. Kopas-Vukašinović i B. Stojanović (ur.), Savremeno predškolsko vaspitanje i obrazovanje: izazovi i dileme (297-313). Jagodina: Fakultet pedagoških nauka Univerziteta u Kragujevcu. Preuzeto 20.1.2022. sa Danijela-Apostolović-KURIKULUMIPREDŚKOLSKOG-VASPITANJA-KAO-OSNOVA-ZA PLANIRANJE-IPROGRAMIRANJE-RADA-VASPITAČA-U-PREDŠKOLSKOJ-USTANOVI. pdf (kg.ac.rs)

Balen, M. (2019). Alternativne pedagogije u ranom i predškolskom odgoju [Završni rad, Sveučilište u Zagrebu, Učiteljski fakultet]. Preuzeto 19.1.2022. sa Alternativne pedagogije u ranom i predškolskom odgoju | Digitalni repozitorij Sveučilišta u Zagrebu (unizg.hr)

Bashayi, A. S. (2015). Tabula Rasa Theory: A Basis for Creativity and Inventions in Education. Journal of Resourcefulness and Distinction, 11(1). Preuzeto 19.1.2022. sa ARIKS SAMUEL 26.pdf (globalacademicgroup.com)

Bašić, S. (2011). Modernost pedagoške koncepcije Marije Montessori. Pedagogijska istraživanja, 8(2), 205-214. Preuzeto 07.9.2021. sa https://hrcak.srce. hr/116671

Bruner, J. (2000). Kultura obrazovanja. Zagreb: Educa.

Crowley, K. (2017). Child development: A practical introduction. London: Sage.

Čeko, L. (2021). Uloga odgajatelja u dječjoj igri [Završni rad, Univerzitet u Splitu, Filozofski fakultet, Odsjek za predškolski odgoj]. Preuzeto 19.1.2022. sa Uloga odgajatelja u dječjoj igri | repozitorij.ffst.unist.hr

Čizmić, I. i Rogulj, J. (2018). Plastičnost mozga i kritična razdoblja - implikacije za učenje stranoga jezika. U: D. Zlatović (ur.), Zbornik radova veleučilišta u Šibeniku 1-2/2018 (115-126). Veleučilište u Šibeniku. Preuzeto 07.10.2021. sa https://hrcak.srce.hr/198556

Državni pedagoški standard predškolskog odgoja i naobrazbe (2008). Narodne novine, br. 63/08. https://narodne-novine.nn.hr/clanci/sluzbeni/2008_06_63_2128.html

Gomerčić, L. (2020). Alternativni koncepti i poticanje kreativnosti u vrtiću - pe- 
dagogija Montessori. U: G. Gojkov i A. Stojanović (ur.), Kompleksnost fenomena darovitosti i kreativnosti - izazovi: pojedinac i društvo (133-139). Vršac - Arad: Visoka škola strukovnih studija za vaspitače „Mihailo Palov” - Universitatea de Vest „Aurel Vlaicu”. Preuzeto 19.1.2022. sa Microsoft Word - 17 - Gomercic.doc (uskolavrsac.edu.rs)

Gopnik, A., Meltzoff, A. N. i Kuhl, P. K. (2003). Znanstvenik u kolijevci: što nam rano učenje kazuje o umu. Zagreb: Educa.

Gray, C., \& MacBlain, S. (2015). Learning theories in childhood. Sage.

Grđan, Z. (2008). Interkulturalna pedagogija - sukonstrukcija kurikuluma cjeloživotnog odgoja i suvremene škole. U: V. Uzelac i L. Vujčić (ur.), Zbornik: Cjeloživotno učenje za održivi razvoj. Plitvice: Učiteljski fakultet u Rijeci.

Jozipović, M. (2021). Usporedba Waldorfi Montessori koncepcije ranog i predškolskog odgoja i obrazovanja [Završni rad, Sveučilište u Splitu, Filozofski fakultet, Odjel za rani i predškolski odgoj i obrazovanje]. Preuzeto 19.1.2022. sa Usporedba Waldorf i Montessori koncepcije ranog i predškolskog odgoja i obrazovanja | The University of Split Repository (unist.hr)

Jurčević-Lozančić, A. (2011). Teorijski pogledi na razvoj socijalne kompetencije predškolskog djeteta. Pedagogijska istraživanja, 8(2), 271-279. Preuzeto sa https://hrcak.srce.hr/index.php?id_clanak_jezik=172458\&show=clanak

Knudsen, E. I. (2004). Sensitive periods in the development of the brain and behavior. Journal of cognitive neuroscience, 16(8), 1412-1425. Preuzeto 19.1.2022. sa Sensitive Periods in the Development of the Brain and Behavior | MIT Press Journals \& Magazine | IEEE Xplore

Konvencija o pravima djeteta (2001). Zagreb: Državni zavod za zaštitu obitelji, materinstva i mladeži. Preuzeto10.9.2021. sa Konvencija o pravima djeteta (gov.hr)

Krstović, J. (2009). Odrazi sveučilišnog obrazovanja odgajatelja na koncept novog profesionalizma: izazovi i dileme. U: D. Bouillet i M. Matijević (ur.), Kurikulumi ranog odgoja i obveznog obrazovanja (173-184). Zagreb: Učiteljski fakultet.

Lazić T. S. i Colić, V. (2017). Kontekstne dimenzije u jaslama viđene očima budućih vaspitača. Nastava i vaspitanje, 66(1), 129-142. Preuzeto 19.1.2022. sa 0547-33301701129L.pdf (ceon.rs)

Maleš, D. (2011). Nove paradigme ranoga odgoja. Zagreb: Filozofski fakultet Sveučilišta u Zagrebu, Zavod za pedagogiju.

Miljak, A. (2007). Teorijski okvir sukonstrukcije kurikuluma ranog odgoja. U: V. Previšić (ur.), Kurikulum: teorije-metodologija-sadržaj-struktura. Zagreb: Zavod za pedagogiju Filozofskog fakulteta Sveučilišta u Zagrebu - Školska knjiga.

Miljak, A. (2009). Življenje djece u vrtiću: novi pristupi u shvaćanju, istraživanju i organiziranju odgojno-obrazovnog procesa u dječjim vrtićima. Zagreb: SM naklada d.o.o.

Ministarstvo prosvjete i športa. (1991). Prijedlog koncepcije ranog odgoja i obrazovanja u Republici Hrvatskoj. Zagreb: Glasnik Ministarstva kulture i prosvjete, broj 7/8, 1991.

Nacionalni kurikulum za rani i predškolski odgoj i obrazovanje. Narodne novine, br. 5/15. Preuzeto sa https://narodne-novine.nn.hr/clanci/sluzbe- 
ni/2015_01_5_95.html (15.10.2021.)

Petrović-Sočo, B. (2007). Kontekst ustanove za rani odgoj i obrazovanje - holistički pristup. Zagreb: Mali profesor.

Petrović-Sočo, B. (2008). Osobne vrijednosti u kontekstu cjeloživotnog učenja odgojitelja/učitelja. U: M. Cindrić, V. Domović i dr. (ur.), Pedagogija i društvo znanja (sv.1, 281-291). Zagreb: Učiteljski fakultet.

Petrović-Sočo, B. (2009). Značajke suvremenog naspram tradicionalnog kurikuluma ranog odgoja. Pedagogijska istraživanja, 6(1-2), 123-136. Preuzeto 14.10.2021 sa https://hrcak.srce.hr/118104

Pešikan, A. (2010). Savremeni pogled na prirodu školskog učenja i nastave: Sociokonstruktivističko gledište i njegove praktične implikacije. Psihološka istraživanja, 13(2), 157-184. Preuzeto 14.10.2021. sa https://www.researchgate.net/ profile/Ana_Pesikan2/publication/307747477

Previšić, V. (2007). Kurikulum: teorije, metodologija, sadržaj, struktura. Zagreb: Školska knjiga.

Programsko usmjerenje odgoja i obrazovanja predškolske djece (1991). Zagreb: Glasnik Ministarstva kulture i prosvjete, broj 7/8, 2.

Robson, S., \& Smedley, S.(1996). Education in early childhood: first things first. London: David Fulton Publishers - Roehampton Institute.

Rogulj, E. (2018). Child and Institutions: Institutional Childhood. Croatian Journal Educational / Hrvatski časopis za odgoj i obrazovanje, 20, 131-147. Preuzeto 15.10.2021. sa https://doi.org/10.15516/cje.v20i0.3053

Seitz, M., \& Hallwachs, U. (1996). Montessori ili Waldorf?. Zagreb: EDUCA.

Siegel, D. J., \& Payne Bryson. T. (2015). Razvoj dječjeg mozga: 12 revolucionarnih strategija integriranog pristupa za poticanje razvoja zdravoga dječjega uma, preživljavanje svakodnevnih roditeljskih borbi i za poticanje cjelokupnoga rasta $i$ razvoja obitelji. Split: Harfa.

Slunjski, E. (2008). Dječji vrtić: zajednica koja uči: mjesto dijaloga, suradnje, i zajedničkog učenja. Zagreb: Spektar media.

Slunjski, E. (2012). Tragovima dječjih stopa. Zagreb: Profil International.

Sviben, M. (2020). Temeljne značajke Waldorf pedagogije [Završni rad, Sveučilište u Splitu, Filozofski fakultet, Odsjek za predškolski odgoj]. Preuzeto 19.1.2022. sa Temeljne značajke Waldorf pedagogija | Nacionalni repozitorij završnih i diplomskih radova ZIR (nsk.hr)

UNESCO. (2005). Guidelines for Inclusion: Ensuring Access to Education for All. Preuzeto 19.1.2022. sa Guidelines for inclusion: ensuring access to education for all; 2006 (unesco.org)

Van Praag, H., Kempermann, G., \& Gage, F. H. (2000). Neural consequences of enviromental enrichment. Nature Reviews Neuroscience, 1(3), 191-198. Preuzeto 19.1.2022. sa Neural consequences of enviromental enrichment | Nature Reviews Neuroscience

Vlastelica, M. (2014). Rani odnos majka-dijete u svjetlu neuroznanstvenih spoznaja. Zagreb: Medicinska naklada.

Wikefeldt, U. (2011). Maria Montessori - holistički pristup životu. U: H. Ivon, L. Krolo i B. Mendeš (ur.), Pedagogija Marije Montessori - poticaj za razvoj pedagoškog pluralizma (47-59). Split: Dječji vrtić Montessori dječja kuća - Udru- 
ga Montessori pedagogije. Preuzeto 19.1.2022. sa Skolski_vj._br.1-2012..indd (srce.hr)

Woodhead, M. (2012). Različite perspektive o ranom djetinjstvu: teorija, istraživanje i politika. Beograd: CIP - Centar za interaktivnu pedagogiju.

Zakon o predškolskom odgoju (1997). Narodne novine, Zagreb, 1997, br.10. Preuzeto 19.1.2022. sa Zakon o predškolskom odgoju i naobrazbi (nn.hr)

Zmajlović, M. (2016). Montessori pedagogija. [Diplomski rad. Sveučilište u Zagrebu, Učiteljski fakultet, Katedra za pedagogiju i didaktiku]. Preuzeto 19.1.2022. sa Monterssori pedagogija | Nacionalni repozitorij završnih i diplomskih radova ZIR (nsk.hr)

\author{
Anamarija Klišanić \\ Ines Vrsalović Nardelli \\ "Maksimir" Kindergarten \\ Zagreb, Croatia
}

\title{
CONTENPORARY PERSPECITVE ON CHILDREN IN THE INSTITUTIONAL CONTEXT IN CROATIA
}

\begin{abstract}
Contemporary perspective on children and recognition of the importance of a holistic approach as a way to achieve their maximum well-being in terms of development and learning have encouraged both theorists and practitioners to deliberate upon these subjects. The National Curriculum for Early and Preschool Education (2015) was created as a result of the New Childhood Paradigm, which perceives children as creators of their own educational process, and the synergy of theorists and practitioners in the field of education in the Republic of Croatia. Unlike the traditional understanding of children and childhood, focused more on the result of learning than on the learning process, the modern approach accepts children as creators of their own educational process, fulfilling the socio-pedagogical, spatial and temporal dimensions which are permanently intertwined in the institutional context. Understanding the modern curriculum, which approaches the child in a completely new way, requires children and adults to learn together within a humanistic and socio-constructivist environment. Abandoning traditional understanding of children and childhood, which sees them as a blank canvas that yet remains to be filled in the institutional context, and accepting contemporary knowledge raised awareness of the importance of rethinking practitioners' personal pedagogies and encouraged them to lifelong learning. It also brought to attention the need to develop kindergarten culture manifested in the quality of the relationship of all the adults and children involved in the educational process.
\end{abstract}

Keywords: competencies, institution culture, curriculum, paradigms. 